\title{
The Effect of Capital Structure and Operating Leverage on Going Concern Opinion with Profitability as Intervening Variables in Property and Real Estate Sub Sector Services Companies Listed on the Indonesia Stock Exchange for the 2014-2019 Period What is the Profitability to Mediate the Going Concern Audit Opinion: Empirical Evidence on Developing Capital Markets
}

\author{
Neneng Aidatul Fadhilah', MF. Arrozi ${ }^{2}$ \\ ${ }^{1,2}$ Esa Unggul University
}

\begin{abstract}
The purpose of this study is to empirically examine the effect of capital structure and operating leverage on going concern opinions with profitability as an intervening variable. The population of this research is the property and real estate subsector service companies listed on the Indonesia Stock Exchange in the 2014-2019 period, which are 65 companies. The sample in this study amounted to 15 companies and had 90 observational data that had been selected using the purposive sampling method. The data used in this study is secondary data obtained from the Indonesia Stock Exchange (IDX) and data analysis using Logistics Regression analysis. The results of this study indicate that capital structure, operating leverage and profitability have a positive influence on going concern opinions and capital structure and operating leverage have no effect on profitability and even profitability is not able to mediate the effect of capital structure on operating leverage, to the going concern opinion.
\end{abstract}

KEYWORDS: Capital Structure, Going Concern Opinion, Operating Leverage and Profitability.

\section{INTRODUCTION}

Quoted from Kompas.Com on Monday, May 11, 2020 that the COVID-19 pandemic caused by the middle of the SARS-Cov-2 has hit the whole world, leading to the peak of the crisis in various aspects. Apart from claiming tens of thousands of victims worldwide, the outbreak has also disrupted economic activity in various sectors. The implementation of the closure policy and the presence of other policies became an obstacle to the spread of Covid-19 and caused the wheels of the economy to spin as if it had stopped, until it finally reached an economic crisis. When the impact of the Covid-19 pandemic began there, the rate of economic growth for the whole world felt a dramatic drop (Adhikara, et al., 2022). The Covid-19 pandemic has affected all business fields, including the property business. Before the corona pandemic, the real estate industry development was actually positive after some time ago it was stagnant.

Therefore, according to Aria, (2015) The sustainability of a business or what is often referred to as the Pursuit of Interest is an important consideration for company management and also for potential shareholders in the long term. Outgoing worries are also referred to as continuity. This shows that the company continues to grow and continues to carry out its activities such as completing projects, completing agreements and completing ongoing operations. The current business continuity assessment is based more on a company's ability to continue as a going concern, and over the next 12 months, the company can see progress. To draw preliminary and basic conclusions about whether business will continue, the auditor must be able to critically evaluate the company's existing management plans.

There were several cases, such as PT BPR Akarum (Central Sulawesi) 2018 which was liquidated quoted from lps.go.id, then there was also Pertamina Energy Trading Ltd (Petral) which was liquidated according to a quote from oilgas .esdm.go. jw.org en on Wednesday, May 13, 2015. When compiling a report, an accounting firm said that the situation of a bank or company that was considered good by the presence of a non-standard opinion was in fact bad. This phenomenon often occurs in real estate 


\section{International Journal of Current Science Research and Review}

ISSN: 2581-8341

\section{Volume 05 Issue 02 February 2022}

DOI: 10.47191/ijesrr/V5-i2-21, Impact Factor: 5.825

companies, where real estate companies also have a relationship with business continuity audit opinions, especially from several companies.

According to (Aria, 2015) in his research said that the quality of liquidity, audit, and profitability cannot have an influence on perceptions that provide benefits, while solvency has an influence on perceptions of supporters. According to (Aria, 2015) found that, in his study, solvency (using DER as a benchmark) affects the acceptance of sustainable corporate audit reports (GCARs). Meanwhile, according to the results of the research program (Haryanto and Sudarno, 2019), the solvency ratio (DIR) does not seem to affect going concern audit opinions on manufacturing companies listed in Indonesia. His research (Sukmayanti and Triaryati, 2019) shows that the variables in the capital structure have a good effect on profitability. In other words, an increase in capital structure does not reflect an increase in profitability.

His research (Sukmayanti and Triaryati, 2019) shows that the variables in the capital structure have a good effect on profitability. In other words, an increase in capital structure does not reflect an increase in profitability. On the other hand (Tandi et al., 2018) in his study found the results of the capital structure that had no effect on profitability. However, his study conducted by Kumalasari (2016) shows that partial operating leverage has a positive value on profitability. However, high costs indicate that profitability is higher than product differentiation. Where operating leverage is used to measure the ability to use fixed costs to increase sales from EBIT. In other words, the higher the operational costs, the higher the risk.

The research contribution is to develop information that is communicated to other users of information by using normative accounting theory (Budiarto \& Murtanto, 1999) which tries to explain what should be done in the process of presenting financial information to users. Thus, to form awareness among companies, investors and other users regarding the importance of business continuity information in a company that can be used as a benchmark in making investment decisions in the future.

The purpose of the study was to obtain empirical evidence of capital structure and operating leverage on going concern opinions with profitability as an intervening variable.

\section{THEORY AND HYPOTHESES DEVELOPMENT}

\section{Normative Accounting Theory}

According to (Budiarto \& Murtanto, 1999) normative theory is a theory that seeks to explain information communicated to other users of information. In other words, normative theory tries to explain what should be done (what should be done) in the process of presenting financial information to users. However, according to Radwan (2007) standard accounting theory is a theory that tries to answer a question whether accounting costs are better than operating costs in achieving accounting goals. When accounting standards are applied, no matter what, accounting standards become the norm. Because standard accounting theory has full value, accounting standards correspond to value. For this reason, companies when compiling and presenting their financial statements and users when interpreting or interpreting their financial statements (Krismiaji \& Murwani, 2013).

\section{Signaling Theory}

Signal theory is information published in the form of advertisements that will be a signal for investors to make investment decisions. If an advertisement has real value, it is expected that the market will respond and be welcomed by the market. Disclosure of accounting information, including timely submission of financial reports, provides a signal (good news) that the company has good prospects, so that investors can be interested in trading their shares (Andriana and Raspati, 2015). According to (Nurmiati, 2016), signaling theory is a signal that provides information asymmetry to the company in managing the parties involved in an information acquisition.

\section{Effect of Capital Structure on Going Concern Opinion}

Capital structure is the financing of a company by comparing and assimilating debt and preferred stock (Brigham \& Houston, 2015). Capital structure using (DER). His findings (Aria, 2015) show that the ability to pay (using DER as an opportunity) affects the acceptance of sustainable audit reports (GCARs). Meanwhile, according to the results of the research program (Haryanto and Sudarno, 2019), the solvency ratio (CFR) does not seem to affect going concern opinions on manufacturing companies listed in Indonesian securities. This is because the auditor takes into account the company's overall financial position when compiling the current audit report and believes that the company will be able to pay off all its debts. 


\title{
International Journal of Current Science Research and Review
}

ISSN: 2581-8341

\author{
Volume 05 Issue 02 February 2022
}

DOI: 10.47191/ijesrr/V5-i2-21, Impact Factor: 5.825

IJCSRR@ 2022

www.ijcsrr.org

\section{Effect of Operating Leverage against Opinion Going Concern}

According to Wijaya (2011) from Epayanti (2014) business risk is reflected in companies that have set operational costs, where existing companies use what is called operating influence. According to Sartono (2010) by Ibayante (2014) the size of the level of operating leverage (DOL) will affect companies with a fairly high level of activity and companies with a relatively low level of risk. A tested study (Yovalia \& Wibowo, 2016) found that business risk as a metric with operating leverage continues to have no impact on the business. This is because the small transaction rate (DOL) has a large impact on the company and low business risk. The higher the DOL value, the riskier the company is.

\section{Effect of Profitability on Going Concern Opinion}

The measure of the level of success and operational efficiency of the company is based on the level of profitability that has been achieved by the company. Where the profits obtained by the company come from product sales and from investments in the company (Rudangga and Sudiartha, 2014). In a study conducted (Arma, 2013) shows that cost effectiveness has a negative impact on ongoing opinion. This shows that the relationship between profitability and audit reports is said to be consistent with the fact that the higher the income, the smaller the possibility of an opinion. According to research (Aria, 2015), the results of the above study indicate that profitability does not affect the company's going concern audit opinion.

\section{Effect of Capital Structure on Profitability}

Capital structure shows how much the company can finance with capital and equity while profitability shows how much profit the company can generate. If the capital structure is low, it should not reflect the company's maximum ability to secure debt with capital, or the reduction in capital structure should not be one-way with profitability. Studies from (Ni Wayan and Tri Aryati, 2019; Mala et al., 2021) find that capital structure has a significant effect on the profitability of real estate companies listed on the IDX (Indonesian Stock Exchange) in 2014-2019. This illustrates that the increase in capital structure does not increase. The faster the company's capital structure, the higher the level of capital used in running the business so that it does not affect the company's profits. This is different from the finding (Tandi et al. 2018) that capital structure does not affect profitability.

\section{Effect of Operating Leverage on Profitability}

Reporting from a study reviewed by (Kumalasari, 2016), shows that the effect of operating leverage has a significant positive impact on profitability because the high burden that the company bears will increase profits but based on the interpretation at the beginning of the high load will reduce the company's profit level, namely profitability. The higher the load can increase, it is an indication of the company distinguishing new products with investments. The use of Operating Leverage can be seen from the ability to use fixed costs, namely the increase in EBITDA volume. In other words, the higher the fixed costs, the higher the risk (Kumalasari, 2016). The results above indicate that there is no effect of operating leverage (DOL) on an inconsistent profitability which requires an increase in operating leverage.

Effect of Capital Structure and Operating Leverage on Going Concern Opinion through Profitability as an Intervening Variable.

The Effect of Capital Structure, Operating Leverage and Profitability Simultaneously Affects Going Concern Opinions Hypothesis Development

Based on the literature review and the results of previous studies, the hypotheses are formulated as follows:

- H1: Capital Structure Positively Affects Going Concern Opinion

- H2: Going Concern Opinion has a positive effect on Operating Leverage

- H3: Going Concern Opinion has a positive effect on Profitability

- H4: Capital Structure has a Positive and Significant Effect on Profitability.

- H5: Operating Leverage Has a Positive And Significant Effect on Profitability.

- H6: Profitability Can Mediate the Effect of Capital Structure and Operating Leverage on Going Concern Opinion

- H7: Capital Structure, Operating Leverage And Profitability Simultaneously Affect Going Concern Audit Opinion 


\section{International Journal of Current Science Research and Review}

ISSN: 2581-8341

Volume 05 Issue 02 February 2022

DOI: 10.47191/ijcsrr/V5-i2-21, Impact Factor: 5.825

IJCSRR@ 2022

WWW.ijcsrr.org

\section{RESEARCH METHODS}

\section{Research design}

The research design used the association method. Collecting data through documentation and literature study. Quantitative data with secondary data sources. The research population is property and real estate sub-sector service companies on the Indonesia Stock Exchange during the 2014-2019 survey period. The sampling technique is purposive sampling. The research sample is 15 companies. Data analysis using path analysis.

\section{Variable Operational Definition}

Going concern opinion which is a perception placed by the auditor on the company's ability assessment aimed at maintaining the continuity of the company. Where the audit report currently enforced is an opinion without a basis, namely an opinion with exceptions, and an opinion without basis. Audit opinion is outlined by using a dummy variable, namely two variables with different levels (Sikaran, 2010).

The capital structure in this study is similar to the leverage ratio or solvency ratio, which shows how much money the company collects with debt, and the company's ability is explained by capital. In this study, using the equity ratio (DER) as a measure of leverage. DER is a comparison of debt and equity in a company's finances.

Operating leverage or operating leverage shows how an income or sale can affect an operation. Knowing how much operating leverage allows management to predict how operating profit will change. This shows the operating leverage which has a relationship with income, profit before tax. Operating leverage is measured by the degree of operating leverage (DOL). Operating leverage also shows the impact of profit on operating profit or earnings before interest and taxes (EBIT). This effect can be determined by calculating the level of operating leverage.

According to (Fahmi, 2016), Profitability is a measure of the effectiveness of public administration which is determined by measuring the level of profits obtained from the exchange and exchange of money. Gross profit margin (GPM) as a measure of profitability in this study. The higher the gross margin, the better the company's performance (efficiency). This value indicates that the sales value is less than the sales value and is useful for operational audits. Otherwise, the company is considered inferior in the implementation of its operational activities.

\section{RESULTS AND DISCUSSION}

\section{Research result}

\section{Descriptive Statistics}

The statistical descriptive results show the going-concern opinion which is shown in table 1.

Table 1. Descriptive Statistics Calculation Results

\begin{tabular}{|l|l|l|l|l|l|}
\hline & N & Minimum & Maximum & Mean & Std. Deviation \\
\cline { 1 - 5 } DER & 90 & .06 & 3.50 & .6910 & .52328 \\
DOL & 90 & -38.01 & 80.88 & 3.3137 & 11.94077 \\
PROFIT & 90 & .16 & 1.88 & .5893 & .25232 \\
GC & 90 & .00 & 1.00 & .4889 & .50268 \\
Valid N (listwise) & 90 & & & & \\
\hline
\end{tabular}

Source: Processed Data

Testing Requirements Analysis

Assessing the Feasibility of the Regression Model (Hosmer and Lemeshow's Goodness of Fit Test) Below are the test results of Hosmer and Lemeshow's Goodness of Fit Test.

Table 2. Hosmer and Lemeshow's Goodness of Fit.Test

\begin{tabular}{|l|l|l|l|}
\hline Step & Chi-square & df & Sig. \\
\cline { 1 - 3 } & 4.942 & 8 & .764 \\
\hline
\end{tabular}

Source: Processed Data 


\section{International Journal of Current Science Research and Review}

ISSN: 2581-8341

Volume 05 Issue 02 February 2022

DOI: 10.47191/ijesrr/V5-i2-21, Impact Factor: 5.825

IJCSRR@ 2022

Www.ijcsrr.org

Based on the results of data processing on SPSS 21, it is known that the Hosmer-Lemeshow statistical test has a dominating probability that is 0.76 greater than 0.05 . The probability number is 0.76 which is 0.05 then Ho is accepted. This means that the feasibility of the regression model analysis does not have a significant difference between the clarification of predictions and clarification of observations.

Overall Model Fit (Model Fit Assessment of Overall Model Below are the results of the Overall Model Fit test.

Table 3. Overall Model Fit (Block Number $0=$ Initial)

Iteration History ${ }^{a, b, c}$

\begin{tabular}{|l|l|}
\hline Iteration & -2 Logs likelihood \\
& \\
\hline 1 & 124,722 \\
Step 0 & 124,722 \\
2 & \\
\hline
\end{tabular}

Source: Processed Data

Table 4. Overall Model.Fit (Block Number 1 = Initial) Model Summary

\begin{tabular}{|l|l|l|l|l|}
\hline Step & $\begin{array}{l}\text {-2 Logs likelihood } \\
\text { y }\end{array}$ & $\begin{array}{l}\text { Cox \& Snell R } \\
\text { Square }\end{array}$ & $\begin{array}{l}\text { Nagelkerke } \\
\text { Square } \\
220\end{array}$ \\
\hline
\end{tabular}

a. Estimation terminated at literacy number 5 because parameter estimates changed by less than .001 .

Source: Processed Data

The results of SPSS 21 data processing, it is known that the probability value of the initial 2 logs (beginning of 2LL) in block number $=0$ is 124.722 , which is the probability of the final $2 \operatorname{logs}(2 \mathrm{LL})$ in block number increasing. $=1$ is 108,509 . This result indicates a reduced probability. This means that this regression model can be said to be a good model, namely hypothetical according to the data.

\section{Hypothesis test}

Coefficient of Determination Test ( Nagelkerke $\boldsymbol{R}$ Square) The following are the test results from Nagelkerke $R$ Square.

Table 5. Nagelkerke R Square Model Summary

\begin{tabular}{|l|l|l|l|l|}
\hline Step & -2 Logs likelihood & $\begin{array}{l}\text { Cox \& Snell R R } \\
\text { Square }\end{array}$ & $\begin{array}{l}\text { Nagelkerke } \\
\text { Square } \\
220\end{array}$ \\
\hline 1 & $108,509^{\mathrm{a}}$ & .165 & .220 \\
\hline
\end{tabular}

a. Estimation terminated at iteration number 5 because parameter estimates changed by less than .001 .

Source: Processed Data

Based on data processing on SPSS 21 the amplitude of the Nagelkerke R Square value is 0.220, namely the variability of the dependent variable can be considered to have a value of $22 \%$ while $78 \%$ can be explained by other factors not included in this study.

\section{Hypothesis Test Results}

The test results on the hypothesis of equation 1 can be seen in the following table: 


\section{International Journal of Current Science Research and Review}

ISSN: 2581-8341

Volume 05 Issue 02 February 2022

DOI: 10.47191/ijesrr/V5-i2-21, Impact Factor: 5.825

IJCSRR@ 2022

Table 6. Test Results. Hypothesis 1 Variables in the Equation

\begin{tabular}{|c|c|c|c|c|c|c|c|}
\hline & & B & SE & Wald & df & Sig. & $\operatorname{Exp}(B)$ \\
\hline \multirow[t]{5}{*}{ Step $1^{a}$} & PROFIT & 3.288 & 1.445 & 5.175 & 1 & .023 & 26,785 \\
\hline & DER DOL & 1.061 & .523 & \multirow{3}{*}{$\begin{array}{r}4.118 \\
4004\end{array}$} & 1 & .042 & 2,890 \\
\hline & & $.054-2.824$ & .027 & & & & \\
\hline & & & .956 & & 1 & .045 & 1.035 \\
\hline & Constant & & & 8,731 & 1 & .003 & .059 \\
\hline
\end{tabular}

a. Variable(s) entered.on step 1: PROFIT, DER, DOL.

Source: Processed Data

The results of the hypothesis test of equation 2 can be seen from the following table:

Table 7. Hypothesis Test Results 2 Coefficients ${ }^{\text {a }}$

\begin{tabular}{|c|c|c|c|c|c|c|}
\hline \multirow{2}{*}{\multicolumn{2}{|c|}{ Model }} & \multicolumn{2}{|c|}{ Unstandardized Coefficients } & \multirow{2}{*}{$\begin{array}{l}\text { Standardized } \\
\text { Coefficients } \\
\text { Beta }\end{array}$} & \multirow[b]{2}{*}{$\mathrm{t}$} & \multirow[b]{2}{*}{ Sig. } \\
\hline & & $\mathrm{B}$ & Std. Error & & & \\
\hline \multirow[t]{3}{*}{1} & (Constant) & .600 & .046 & & 13.009 & .000 \\
\hline & DER & -.005 & .052 & -.011 & -.105 & .917 \\
\hline & DOL & -.002 & .002 & -.098 & -.915 & .363 \\
\hline
\end{tabular}

a. Dependent Variable: PROFIT

Source: Processed Data

From the results of SPSS 21 in tables 6 and 7 it can be formulated with the regression equation as follows:

$$
\begin{array}{ll}
\text { GC } & =-2.824+1.061 \text { DER }+0.054 \text { DOL }+3.288 \text { PROFIT }+e \\
\text { GPM } & =0.600-0.005 \text { DER }-0.002 \text { DOL }
\end{array}
$$

\section{Mediation Test Results}

To test the effect of capital structure and operating leverage on business continuity through profitability as an intermediary variable, an intermediary test was conducted using the Sobel test. The following is an explanation of the table as follows:

Table 8. Sobel Test Results

\begin{tabular}{|l|l|}
\hline Variable & t count \\
\hline $\mathrm{DER} \rightarrow \mathrm{GPM} \rightarrow \mathrm{GC}$ & -0.020 \\
\hline $\mathrm{DOL} \rightarrow \mathrm{GPM} \rightarrow \mathrm{GC}$ & -0.054 \\
\hline
\end{tabular}

\section{Simultaneous Hypothesis Testing}

Below are hypotheses that were tested and worked on simultaneously.

Table 9. Simultaneous Hypothesis Testing

Omnibus Tests of Model Coefficients

\begin{tabular}{|ll|l|l|l|}
\hline & & Chi-square & df & Sig. \\
\hline Step 1 & Step & 16,213 & 3 & .001 \\
& Block & 16,213 & 3 & .001 \\
& Model & 16,213 & 3 & .001 \\
\hline
\end{tabular}




\section{International Journal of Current Science Research and Review}

ISSN: 2581-8341

Volume 05 Issue 02 February 2022

DOI: 10.47191/ijesrr/V5-i2-21, Impact Factor: 5.825

IJCSRR@ 2022

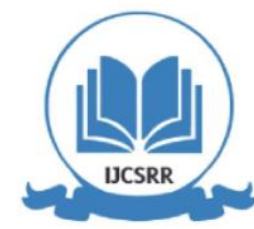

www.ijesrr.org

Based on the results of data processing in SPSS 21 above, it shows that the significant value is 0.001 which is less than the significant level value of $0.05(5 \%)$, it can be concluded that the capital structure, operating leverage and profitability have a simultaneous or joint effect on the going concern opinion. concern.

\section{DISCUSSION}

\section{Effect of Capital Structure on Going Concern Opinion}

The results of the first hypothesis (H1) indicate that the capital structure affects going-concern opinion. The results of the analysis show that the non-standard beta coefficient of the capital structure variable is 1.061 and (Sig.) T is 0.02 . that is $\mathbf{H 1}$ is said to be accepted. This is in line with the study conducted by (Aria, 2015) in his research that solvency (using DER as a benchmark) affects going concern opinion (GCAR). The results of this study explain that the increased DER costs of companies can provide insight into more debt-based corporate financing. This can cause lenders to doubt the loan offer, which can lead to financial instability. This can jeopardize the company's business continuity to increase the auditor's confidence in providing audit reports on business continuity.

A good company's capital structure can be used as company information. This information is very important for investors because basically an information record or description of past and present conditions as well as the future is the sustainability of the company. This is the same as signal theory which explains that companies tend to report to external parties. Where the company insists on providing information asymmetry with external parties, because the information has more prospects in the future.

(investors and creditors).

\section{Effect of Operating Leverage on Going Concern Opinion}

The second hypothesis (H2) is that operating leverage has an effect on going concern opinion. The results of the analysis show that the unstandardized beta coefficient of the operating leverage variable is 0.027 and (sig.) $t$ is 0.045 which is less than 0.05 . That is, $\mathbf{H 2}$ is accepted. The results of the above research are different (Yovalia \& Wibowo, 2016) and show that business risk as an indicator of operating leverage does not affect business continuity. This is because the degree of operating leverage (DOL) affects the level of business risk of a company and affects the survival of the company. A positive sign on the low value of DOL received by the company means that the company is less likely to continue to receive input from the company, and vice versa, the higher the value of DOL, the greater the business risk that must be borne.

According to (Kumalasari, 2016 ) states that companies that find rapid operating leverage have an impact on increasing sales and a significant increase in profits. On the other hand, in the case of firms with low operating leverage, the effect of increased sales on increasing net income is negligible. Operating leverage is calculated from Degrees of Operating Leverage (DOL).

\section{Effect of Profitability on Going Concern Opinion}

The third hypothesis (H3) in this study is that profitability affects going concern opinion. The current analysis shows that the profitability variable has a non-standard beta of 3.288 and a (sig.) with t 0.023 less than 005. This means that H3 is accepted. A positive sign is that if the company is profitable, the auditor tends to state the going concern assumption, and vice versa. The positive sign of the coefficient indicates a one-way relationship. In particular, the higher the gross margin, the better the company will be at maintaining business continuity and the less likely the auditor will influence the opinion. If a low gross margin result indicates that management is not very successful in running the business, the auditor is more likely to give a going concern opinion.

Because high profitability always reflects performance and does not question the going concern assumption, auditors are not required to provide a running company. Second, good profitability determines whether a company can continue its business. The test in this case is consistent with the 2013 Arma study. In other words, profitability affects the auditor's opinion on going concern. However, the results of previous studies show that there is a discrepancy with the research conducted by Aria (2015).

\section{Effect of Capital Structure on Profitability}

The fourth hypothesis (H4) is as a result of the analysis, the non-standard beta coefficient of the capital structure variable is 0.005 (sig.) $t$ is 0.917 , which is smaller (0.05). The conclusion is that the capital structure variable cannot affect profitability (H4 is rejected). This shows that the measured capital structure variable (DER) indicates that the company's capital structure is not abused. The higher the capital structure of the company develops, the more money it generates to support the company's activities. In other words, property and real estate companies cannot increase their profitability by simply changing their debt financing ratio. 


\section{International Journal of Current Science Research and Review}

ISSN: 2581-8341

Volume 05 Issue 02 February 2022

DOI: 10.47191/ijesrr/V5-i2-21, Impact Factor: 5.825

IJCSRR@ 2022

www.ijcsrr.org

The capital structure of a company that is heavily in debt has the small advantage of increasing the interest paid by the company, but the tax paid by the company is low, and vice versa. This discussion is strengthened by the discussion of previous researchers (Novita and Sofie, 2015). The conclusion above is not in line with research findings (Aria, 2015) that DER has an effect on profitability.

\section{Effect of Operating Leverage on Profitability}

The fifth hypothesis (H5) is that as a result of the analysis, the non-standard beta coefficient of the operating leverage variable is 0.002 and (sig.) $\mathrm{T}$ is 0.363 , greater than 0.05 and it can be concluded that the operating leverage variable does not affect profitability ( $\mathbf{H 5}$ is rejected ). ). This benchmark is consistent with studies (Setiawan et al., 2019) and shows that operating leverage (DOL) does not affect profitability.

The results of this study indicate that an increase in operating leverage also reduces the company's profitability, but on the contrary when operating leverage decreases, production costs continue to increase and the company's operating profit increases. This condition tends to reduce company profits due to increased leverage. The findings above are not in line with the findings (Kumalasari, 2016). This illustrates that profitability has an influence on operating leverage.

\section{Effect of Capital Structure and Operating Leverage on Going Concern Opinion through Profitability as an Intervening Variable}

The sixth hypothesis (H6) shows the $\mathrm{t}$ table value $(0.020)$ and the $\mathrm{t}$ count is 1.987 . Therefore $\mathrm{t}$ table is smaller than $\mathrm{t}$ arithmetic which means profitability cannot reflect the effect of capital structure on going concern opinion. It can be concluded that the size of the company's capital structure does not affect the company's viability through going concern opinions. So it can be concluded that the size of the capital structure of the company does not have an impact on the going concern opinion or the survival of a company through profits or profits obtained by the company. So there are other factors that affect business continuity through profitability. The sixth hypothesis (H6) shows the results of the operating leverage test on going concern opinion, namely profitability which is used as an intervention variable. The significance level of $t$ table for $t$ arithmetic $(0.054)$ and $0.05(5 \%)$ is 1.987. Therefore, $\mathrm{t}$ count is smaller than $\mathrm{t}$ table. In other words, profitability cannot reflect the impact of operating leverage on goingconcern opinion. It can be concluded that the company's high and low business risk does not affect the company's proposal or the company's survival through profit or profit. So in conclusion $\mathbf{H 6}$ is rejected.

This shows fluctuating results from each company. Agung Podomoro Land Tbk, for example, reported a decline in gross margin (GPM) for four consecutive years. Namely 0.52 in 2015, 0.50 in 2016, 0.49 in 2017, and 0.48 in 2018 . This decrease is not too significant, but still affects the bottom line and company profits. For property and real estate companies, income calculations are usually carried out over a long period of time, so property and real estate companies not only consider the profitability and profits of the company, but also how property and real estate companies can manage their cash management. To enable companies to use these assets and real estate to conduct business.

Property company and Real estate typically recognizes revenue or profit on an accrual basis at the time of sale (delivery), prior to delivery (prepaid income), or on an agreement basis. Therefore, property companies and companies Real estate usually has a very high level of debt that is used to run the company. So, property companies and real estate has a very long plan, so the profitability of property and real estate companies is different from other companies. Therefore, the value of the property company's profitability and real estate cannot be used as a measure of business continuity or as a measure of business continuity of property and real estate companies.

\section{The Effect of Capital Structure, Operating Leverage and Profitability Simultaneously Affects Going Concern Opinions}

The results of data processing from the effect of capital structure, operating leverage and profitability on going concern opinions show a significant value of 0.001 which is below the significant value of $0.05(5 \%)$, namely $\mathbf{H} 7$ is accepted

\section{RESEARCH FINDINGS}

The results of (DER) show that there is an influence between the two variables. The results of this study are in line with the signaling theory, with investors giving a positive signal that the company is good at managing capital and debt and the company can survive. The results of this study indicate that a company can develop strategies that they can execute correctly and predict business risks. This is a positive signal for the business to remain profitable. The results of the profitability survey (GPM) on the going concern 


\section{International Journal of Current Science Research and Review}

ISSN: 2581-8341

\section{Volume 05 Issue 02 February 2022}

DOI: 10.47191/ijesrr/V5-i2-21, Impact Factor: 5.825

IJCSRR@ 2022

www.ijcsrr.org

opinion show that there is an influence between the two variables. Indeed, profitability is one of the metrics used to assess operational performance. If the company's profit is good, the company will be successful and business continuity will be achieved. High profits represent the health of the business. If a problem is identified the auditor will issue a business continuity prerequisite certificate. The results of this study are in line with the signaling theory which provides a signal for investors to make decisions. The results show that capital structure, operating leverage, and profitability affect business continuity confidence. All three are in line with the normative theory that explains business continuity. Information needed to determine whether a company is feasible or not. The financial information presented is an important consideration for investors in making decisions.

Furthermore, the results show that there is no intermediary in profitability so the business continuity view is based on a direct relationship between capital structure (DER) and operating leverage (DOL), which explains that the size of the firm's capital cannot affect the viability of the concern opinion through the profitability or earnings of the firm and also on operating leverage shows the results that high or low business risk in the company is unlikely to affect the going concern opinion.

\section{CONCLUSION}

Based on the results discussed in the logistic regression analysis, path analysis, and mediation test using the Sobel test, the conclusion is that capital structure, operating leverage and profitability have a positive effect on going concern opinion. Then the capital structure and operating leverage have no effect on profitability. Capital structure and operating leverage cannot mediate profitability on going concern opinion. And capital structure, operating leverage and profitability simultaneously affect going concern opinion.

\section{IMPLICATION}

This research can be used as a reward for shareholders from investing their capital in the company to generate the expected return. For further investigation, we recommend the use of broader variables such as liquidity, audit quality, firm growth, firm size, firm financial position, and other variables. Then, for example, it's a good idea to sample more companies with broad annual coverage, test them, and add more research. This is not only the property and real estate industry, but also other industries. The results can be generalized so that knowledge can be obtained later.

\section{BIBLIOGRAPHY}

1. Andriana, Denny, Raspati, NA (2015). The Effect of Profitability and Public Ownership on Timeliness of Financial Report Submission. Journal of Research in Accounting and Finance, Universitas Pendidikan Indonesia, 3 (2), 649-659.

2. Adhikara, Arrozi, MF, Maslichah, Nur Diana, M. Basjir, 2022, Organizational Performance in Environmental Uncertainty on the Indonesian Healthcare Industry: A Path Analysis, Academic Journal of Interdisciplinary Studies, Vol 11, No 2, ISSN : 2281-4612

3. Arma, Endra Ukti. (2013). The Effect of Profitability, Liquidity, and Company Growth on the Acceptance of Going Concern Audit Opinions (Empirical Study of Manufacturing Companies Listed on the Indonesia Stock Exchange). Padang State University, 1-30.

4. Brigham, EF, \& Houston, JF (2015). Fundamentals of Financial Management, Concise (8th Ed.). Cengage Learning.

5. Budiarto, A., \& Murtanto. (1999). Accounting Theory: From a Normative To a Positive Approach. Stie Ykpn Yogyakarta and Trisakti University Jakarta Recent, Journal of Business and Accounting, 1 (3), 163-182.

6. Fahmi, I. (2016). Introduction to Financial Management: Theory and Questions and Answers. Bandung: Cv. Alphabet.

7. Ghozali, I. (2013). Multivariate Analysis with IBM Spss 21 Program. Semarang: Diponegoro University Publishing Agency.

8. Haryanto, Yoga Adi, S. (2019). The Effect of Profitability, Solvency, Liquidity, and Market Ratios on Going Concern Audit Opinions on Manufacturing Companies on the Indonesia Stock Exchange. Diponegoro Journal Of Accounting, Department of Accounting, Faculty of Economics and Business, Diponegoro University, 8 (4), 1-13.

9. Imaniar, FQ (2016). Factors Affecting Timeliness of Company Financial Reporting. Journal of Accounting Science and Research, Indonesian College of Economics (Stiesia) Surabaya Abstract, 5 (6), 43-56.

10. cashmere. (2015). Financial Statement Analysis. Jakarta:Pt.Raja Grafindo Persada. 


\section{International Journal of Current Science Research and Review}

ISSN: 2581-8341

Volume 05 Issue 02 February 2022

DOI: 10.47191/ijesrr/V5-i2-21, Impact Factor: 5.825

IJCSRR@ 2022

www.ijesrr.org

11. Kevin, X., \& Panjaitan, Y. (2018). Impact of Financial Leverage and Operating Leverage on Company Value in the 20152017 period. Faculty of Economics and Business, Atma Jaya Catholic University,

12. 215-232. Http://Ojs.Atmajaya.Ac.Id/Index.Php/Wpm/Article/View/1218

13. Krismiaji, \& Murwani, AS (2013). Accounting Theory: Literature Review against Normative Theory and Positive Theory. Ykpn Yogyakarta Accounting Academy Abstract, 16 (1), 11-23.

14. Kumalasari, R. (2016). Effect of Operating Leverage and Financial Leverage on Profitability in Telecommunication Companies. Indonesian College of Economics (Stiesia) Surabaya, Journal of Management Science and Research,5 (5).

15. Kuncoro, M. (2013). Research Methods for Business and Economics 4th Edition. Jakarta: Erlangga.

16. Mala, Fath, Chajar Matari, Joel Faruk Sofyan, Muhammad Fachrudin Arrozi Adhikara, Sapto Jumono, 2021, The Relationship Between Banking Intermediation And Real Economic Growth (A Case Study Of Indonesia For The Period 2007-2019), Journal Of Songhwest University Jia, Vol. 56 No. 6, Issn: 0258-272, Pp 551 - 563.

17. Novita, Bunga Asri, S. (2015). Effect of Capital Structure and Liquidity on Profitability. E Journal of Trisakti Accounting, 2 (1), 13-28. Https://Bappenas.Go.Id/Files/2715/8529/3891/ Report_Perkembangan_Ekonomi_Indonesia_Dan_Dunia_ Triwulan_Iv_2019.Pdf.Pdf

18. Nurmiati. (2016). Factors Affecting Timeliness of Nurmiati's Financial Reporting. Faculty of Economics and Business Mulawarman University, Indonesia, Journal of Economics and Management, 13 (2 ), 1-17.

Http://Journal.Feb.Unmul.Ac.Id

19. Pasaribu, AM (2015). The Effect of Auditor Quality, Liquidity, Solvency and Profitability on Going Concern Audit Opinions in the Food and Beverage Sub-Sector Listed on the Indonesia Stock Exchange. Lecturer of Accounting, Faculty of Economics, Al-Azhar University, Medan Abstract, 6 (2), 80-92.

20. Putranto, P. (2018). Factors Affecting the Acceptance of Going Concern Audit Opinions. Mercu Buana University, Online Journal of Accountants, 3 (2), 207-218.

21. Rahyuda, Henny, IAASIGBW (2016). Effect of Business Risk, Company Growth and Capital Structure on Profitability and Value of Manufacturing Companies. E-Journal of Economics and Business, Udayana University, 6, $1729-1756$.

22. Ridwan, A. (2007). Accounting Theory: From Normative To Positive, Value-Free Issues, To Myths And Discourse on Accounting Redefinition. Stisia Surabaya, 8 (1), 16-36.

23. Rudangga, I Gusti Ngurah Gede, GMS (2016). The Effect of Company Growth and Leverage on Profitability and Firm Value. Udayana University Management E-Journal, 5 (7), 4394-4422.

24. Setiawan, OE, Iskandar, Y., Basari, MA, Economics, F., \& Galuh, U. (2019). The Effect of Degree Of Operating Leverage (Dol) And Degree Of Financial Leverage (Dfl) On Profitability (A Study At Pt. Waskita Karya (Persero), Tbk Listed On The Indonesia Stock Exchange Period 2008-2017). Faculty of Economics, Galuh University, Business Management And Entrepreneurship Journal, 1 (2), 149- 157.

25. Siregar, S. 2017. (2017). Quantitative Research Methods: Equipped With Comparison Of Manual And Spss Calculations. Jakarta: Kencana.

26. Sugiyono. (2018). Quantitative, Qualitative, and R\&D Research Methods. Bandung: Cv. Alphabet.

27. Sujarweni, VW (2017). Financial Statement Analysis (Theory, Application and Research Results). Yogyakarta: New Press Library.

28. Sukmayanti, Ni Wayan Prandnyanita; Triaryati, N. (2019). Effect of Capital Structure, Liquidity and Company Size on Profitability in Property and Real Estate Companies. Faculty of Economics and Business, Udayana University, E-Jurnal Management, 8 (1), 7132-7162.

29. Tandi, VP, Tommy, P., \& Untu, VN (2018). The Influence of Capital Structure and Asset Growth on

30. Profitability of Automotive Companies Listed in BEI Period 2013 - 2016. Faculty of Economics and Business Management Department, Sam Ratulangi University, Manado, Emba Journal, 6 (2), 629- 637.

31. Vaniananda Kezyamadea Br Bangun. (2018). The Effect of Audit Quality, Leverage, Profitability and

32. Company Size on the Acceptance of Going Concern Audit Opinions on Property and Real Estate Companies Listed on the Indonesia Stock Exchange. Thesis of the Department of Accounting, Faculty of Economics and Business. University of North Sumatra, 1-92. 


\section{International Journal of Current Science Research and Review}

ISSN: 2581-8341

Volume 05 Issue 02 February 2022

DOI: 10.47191/ijesrr/V5-i2-21, Impact Factor: 5.825

IJCSRR@ 2022

33. Yovalia, S., \& Wibowo, W. (2016). The Influence of Business Strategy and Business Risk on Going Concern in Manufacturing Companies Listed on the Stock Exchange in 2010-2014. Faculty of Economics and Business, Trisakti University, Trisakti Journal of Accounting, 3 (2), 177. Https://Doi.Org/10.25105/Jat.V3i2.4962

34. Https://Properti.Kompas.Com/Read/2020/05/11/080000221/Covid-19-New-Normal-Dan-Krisis-Propertili-?Page=All . www.idx.co.id

35. Http://Iaiglobal.Or.Id/

36. Https://Iapi.Or.Id/

37. Https://Www.Lps.Go.Id/Bank-Yang-Lilikudasi ,

38. Ht tps://Migas.Esdm.Go.Id/Post/Read/Petral-Resmi-Dilikuida si

Cite this Article: Neneng Aidatul Fadhilah, MF. Arrozi (2022). The Effect of Capital Structure and Operating Leverage on Going Concern Opinion with Profitability as Intervening Variables in Property and Real Estate Sub Sector Services Companies Listed on the Indonesia Stock Exchange for the 2014-2019 Period What is the Profitability to Mediate the Going Concern Audit Opinion: Empirical Evidence on Developing Capital Markets. International Journal of Current Science Research and Review, 5(2), 481-491 